\title{
The Strategy and Policy Development of Population Towards the Demographic Bonus 2035 in Kupang District-Indonesia
}

\section{Frans Salesman ${ }^{1 *}$}

${ }^{1}$ High School of Public Health, Citra Husada Mandiri, Kupang, Indonesia

*Corresponding author: Frans Salesman, High School of Public Health, Citra Husada Mandiri, Kupang, Indonesia, Tel: +62 81337909998; E-mail: franssalesman@gmail.com

Received date: May 14, 2018; Accepted date: June 27, 2018; Published date: June 29, 2018

Copyright: (C2018 Salesman F. This is an open-access article distributed under the terms of the Creative Commons Attribution License, which permits unrestricted use, distribution, and reproduction in any medium, provided the original author and source are credited.

\begin{abstract}
Background: Population concerns the number, structure, age, sex, religion, birth, marriage, pregnancy, death, distribution, mobility and quality in the economic, social and cultural. Residents if less managed wisely lead to security disturbances at the national and regional levels. Therefore, comprehensive management touch to the population problem is needed.

Purpose: Produce document as the direction of population development strategy and policy in Kupang district to demographic bonus of 2035 .

Method: Combination of qualitative and quantitative research. Data were obtained through in-depth interview, FGD, Central Biro Statistic publication. 35 people were FGD participants. Implementation of research was scheduled in 60 working days.

Results: The formulation strategy and development policy of Kupang District with target; population 525,706 people, growth rate $1.85 \%$ per year, TFR of 2, NRR 1.12, CBR 22.40, CPR 90\%, CDR 7.03/1000 population, IMR 19.30/1000 live birth, MMR 175/100.000 live birth; Life Expectancy Rate 77.30 years, increasing labor quality, decreasing the number illegal labor abroad. Fertility field policy; availability of demographic information, delaying marriage age, increasing acceptors coverage, continuity of old and new acceptors services, increasing adolescents and couples of childbearing age, provision and distribution of contraceptives, strengthening family economy, enhancing partnerships. Field Mortality; Decrease in maternal mortality during pregnancy, Decrease infant and child mortality, reduce CDR, improve quality of life clean and healthy. Mobility; redistribution of population among subdistricts, equality of development and improvement labor skills.
\end{abstract}

Conclusion: These strategies and policies are used as direction and solution the problem population development in Kupang District UC.

Keywords: Population policy; Fertility; Mobility; Mortality

\section{Introduction}

Population regarding the number of the structure, age, gender, religion, birth, marriage, pregnancy, death, geographical boundaries, mobility and the quality and durability regarding political, economic, social and cultural $[1,2]$. In evaluate population since the time of the creation of man until now always only colored with the dynamics of its problem on various dimensions the population. On the other hand, people can manifests itself as the capital which are used in the development process to produce exodus development, also as the burden of development if the amount is not followed the quality. If managed wisely over its problem the population that occurred on the national and regional cedar can cause disturbance in the security and social welfare. The fact of population in Kupang district reported BPS 2016 describes an indication of the problems of population, indicated by the ten primary indicator; number of 341.220 soul with increment rate population $2.30 \%$ per year, the Total Fertility Rate (TFR) by 3.36 , Nett Reproduction Rate (NRR) 1.44 , Crude Birth Rate (CBR) 25.40, Contraceptive Prevalence Rate (CPR) 83\%, Crude Death Rate (CDR)
9.19/1000 population, infants vascular surgery Rate (IMR) 39.60/1000 live births, Maternal vascular surgery Rate (MMR) 209/100,000 live births and Life Expectancy (Eo Years) 68.66 years [3,4]. Still low quality population marked with lower income per capita, i.e. Rp. 7.085.320, the number of poor citizens 64.940 people (19.03 percent of the total population) and $65 \%$ of the population aged 15 years or above completes the highest education Junior High School. The quality of the population that is described is quite difficult to compete in the millennial. To meet the coming demographic bonus 2035 required the management of comprehensive sectorial touching the population problem in Kupang district.

\section{The Purpose of Research}

Analyzing the projection of population and recommends that the development strategy and policy of population in order to control the number of population in Kupang District until 2035. 


\section{Methods}

\section{Qualitative research method and research Quantitative}

Transmission of research: According to the public policy qualitative research method is done through three stages;. First, the workshop common perceptions about issues such as the population and divination impact if not treated now. Secondly, making Focus Group Discussion (FGD) draws up the agenda and policy recommendations. Third, the arrangement of development policy document population in Kupang district until 2035. The participants of the FGD numbered 35 people, consisting of the head of the Organization of the Kupang District, Members of Regional People's Representative Assembly Kupang District, Head of the Empowerment of Women and Family Planning in Kupang District, non-governmental organizations, community leaders and religious leaders.

Descriptive research method with secondary data processing approach about the scenario of the inhabitants of the results of the analysis of Central Bio Statistic of Kupang district and Central Bio Statistic Province of East Nusa Tenggara [4,5]. The Implementation of research was carried out for sixty working days, from June 012016 until July 312016 , according to the letter of the work orders from the head of the Agency Kupang Father Number. 011.1/562/VI/2016 dated June 012016 about the arrangement of the grand design of the development of population in Kupang district until 2035.

\section{Results and Discussion}

Compiled document content strategy and Population Development Policy until 2035. District as a reference for the long-term development population in Kupang District. This Document as a supplement to the book of Long-Term Development Plan Area Kupang District until 2025. The calculation of the base year is 2015, while the key performance target is the number that will be reached by the end of the year 2035. The details compiled were:

(1) The number of the inhabitants of the year 2035 will be increased from 341.220 to 525.706 , with the rate of increase in the population of an average of $1.85 \%$ per year (decreased from an average of $2.3 \%$ year 2010-2015).

(2) Total Fertility Rate (TFR) will become 2 from 3.36 in 2035.

(3) Net Reproduction Rate (NRR) will become 1.12 from 1.44 in 2035.

(4) Crude Birth Rate (CBR) will become 22.40 from 25.40 in 2035.

(5) Contraseptive Prevalence Rate (CPR) will become 90\% from $83 \%$ in 2035.

(6) Crude Death Rate (CDR) will become 7.03 from 9.19 per 1000 of population in 2035 .

(7) Infants vascular surgery Rate (IMR) will become 19.30/1000 live births from 39.60/1000 live births in 2035.

(8) Maternal vascular surgery Rate (MMR) become 175/100,000 live births from 209/100,000 live births in 2035

(9) Life Expectancy (Eo Years) increases from 68.66 to 77.30 years from the year 2015 .

(10) Increasing the quality of labor.
(11) Declining labor cases of illegal out of the country from an average of 5 cases to 0 cases in the year 2035 .

In Kupang district government policy to achieve the target of development of population:

(1) Fertility: (i) increase the availability of valid and accurate data and information of population; (ii) quantity control population through the delay in the age of marriage, increase coverage acceptor and provision and encircle the evenly contraceptive, continuity of services for the old and new acceptor, Communication improvement and reproductive health education on the young couple and the age of the fertile, strengthening the family economy; (iii) increased partnership with stakeholders;

(2) Mortality: (i) Decrease the number of death in mothers during pregnancy; (ii) decreased infant mortality; (iii) Decrease the number of death coarse, and (iv) increase the quality of life; and

(3) Mobility: (i) A redistribution of population between districts in Kupang; (ii) equitable development in all districts based on the potential and resources available; (iii) improvement of labor skills according to the request of the labor market in the land and abroad; (iv) Development and training center (procuring training facilities for) for labor skill; (v) Implementation of compulsory learning and improvement of the quality of the various levels of education; (vi) improved governance urbanization; and (vii) improvement of social security and guarantee the elders.

\section{Step operationalization through}

(1) Build a harmonious family climate based on marriage validity. (2) Builds resistance family economy. (3) Tackling poverty. (4) Increase the degree of health, education and economic status of the inhabitants. (5) To prevent and combat infectious diseases in infants and children, decrease maternal death. (6) Increase work skills and strengthening the family economy based on local economic resources. (7) Increase the resilience of the family gender perspective based on local institutions. (8) Develop behavior of developing food resilience family. (9) Increase per capita income, increase social and economic independence. (10) Build the life of harmony between man-made members of the family and the community is not divorced, lower levels of domestic violence. (11) Eliminate patterns of human trafficking under the pretext of labor delivery between the regions and abroad. (12) Eliminating trade and the use of narcotics and other forbidden drugs. (13) To reduce the rate of delinquency of children and young people in the community.

\section{Conclusion}

Based on the identification of the problem, trending analysis of population and development strategy and policy district population as solution resolve quantity control and improvement of the quality of the population in Kupang district toward the demographic bonus of 2035.

\section{Acknowledgment}

Successful completion of the publication of this research is possible due to the support from the Chairman of the High School of Health Science Citra Mandiri Kupang, the Head of the Agency Kupang district, Head of Central Biro Statistic of Kupang district, and the parties who have helped us in preparing the data and information during the research in progress. All the assistance and support they gave is priceless. May God bless all of us. Thank you. 
Citation: Salesman F (2018) The Strategy and Policy Development of Population Towards the Demographic Bonus 2035 in Kupang DistrictIndonesia. J Aging Sci 6: 1000190. doi:10.4172/2329-8847.1000190

Page 3 of 3

\section{References}

1. Cut Endang Kurniasih (2014) The concept of the Demographic, the theory of Population and Implementation in some countries.

2. Both Pandawa Alsafrijunery (2016) The understanding of Population according to the Experts.
3. BPS Kupang District 2016 (2016). Kupang District in number. pp. 70-75.

4. BPS Province of East Nusa Tenggara. 2016. East Nusa Tenggara in number 2016.

5. Kupang District health office (2015) Health profile of the Kupang 2015. pp. 38-47. 